\title{
Increased numbers of endothelial progenitor cells in peripheral blood and tumor specimens in non-small cell lung cancer: A methodological challenge and an ongoing debate on the clinical relevance
}

\author{
ANDREAS PIRCHER ${ }^{1}$, CHRISTIAN MATTHIAS KÄHLER ${ }^{1}$, SERGEJ SKVORTSOV ${ }^{1}$, MARGIT DLASKA ${ }^{1}$, \\ GEROLD UNTERGASSER $^{3}$, THOMAS SCHMID ${ }^{2}$, EBERHARD GUNSILIUS ${ }^{3}$ and WOLFGANG HILBE ${ }^{1}$
}

Departments of ${ }^{1}$ General Internal Medicine and ${ }^{2}$ Surgery, Medical University Innsbruck; ${ }^{3}$ Department of
Hematology and Oncology, Tumor Biology and Angiogenesis Laboratory, Innsbruck, Austria

Received July 26, 2007; Accepted September 18, 2007

\begin{abstract}
Bone marrow-derived endothelial progenitor cells (EPC) play an important role in neovascularisation and tumor growth. However, the clinical relevance of EPCs on blood vessel formation in non-small cell lung cancer (NSCLC) is unclear. EPC numbers in circulation are very low and therefore their detection is technically challenging. In the present study, 10 NSCLC patients and 5 healthy controls were included. Patients underwent blood analyses before and after surgery. EPCs were isolated from whole blood by magnetic cell sorting to CD34 (MACS). Afterwards, FACS analyses using antibodies against CD133, CD34, VEGFR2 and CD45 and and immunocytological staining to CD133 on cytospins (MCA) were performed. Cryostat sections of tumor samples were stained for CD133, CD31 and cytokeratin A7. Serum levels of the vascular endothelial growth factor (VEGF) were quantified by sandwich ELISA. Compared to the control group NSCLC patients showed significantly elevated EPC counts and VEGF levels in peripheral blood before and after surgery. From a methodological point of view, the tested procedure (MCA) was validated as compared to the standard FACS analyses $\left(\mathrm{CD} 34^{+} / \mathrm{VEGFR} 2^{+}\right)$. MCA proved to have a very high sensitivity and even allowed the identification of singular positive EPCs.
\end{abstract}

\section{Introduction}

Non-small cell lung cancer (NSCLC) is the leading cause of cancer-related deaths (1). Our knowledge on the carcinogenesis of lung cancer and especially on NSCLC has recently

Correspondence to: Dr Wolfgang Hilbe, Department of Internal Medicine, Innsbruck University Hospital, Anichstrasse 35, A-6020 Innsbruck, Austria

E-mail: wolfgang.hilbe@i-med.ac.at

Key words: lung cancer, immunohistochemistry, CD133, vascular endothelial growth factor, angiogenesis, endothelial progenitor cell improved substantially leading to promising new therapeutic strategies $(2,3)$. Scientific efforts have focused on the growth signalling of the tumor cell itself, and new insights into tumor angiogenesis has led to a new interpretation of tumor growth $(4,5)$.

The tumor growth and metastatic spread in NSCLC correlated with the ability to induce angiogenesis, which is the formation of new blood vessels by the sprouting of preexisting ones (6). Additionally, it has been shown that bone marrow-derived endothelial progenitor cells (EPCs) mobilized by tumor- or ischemic-induced signals may also contribute to neo-vascularisation through a process called vasculogenesis (4). EPCs can be mobilized from the bone marrow and recruited to the sites of neo-angiogenesis by angiogenic growth factors such as vascular endothelial growth factor (VEGF). VEGF is one of the key stimuli of endothelial proliferation and migration and thus plays an essential role in physiological and pathological angiogenesis and has also been reported to correlate with the neo-angiogenesis occurring during cancer (7).

EPCs are a subset of the pluripotent $\mathrm{CD}^{+} 4^{+}$stem cells and are characterised by an endothelial phenotype. 'Early EPCs' found in the bone marrow, are defined by a typical immunological profile, namely by their expression of CD34, CD133 and VEGFR2 (KDR) (8). In particular, the expression of the cell surface marker CD133 (AC133) on a subpopulation of CD34+ human hematopoietic stem cells has been shown to indicate cells destined for endothelial cell differentiation and angiogenesis $(9,10)$. 'Mature EPCs' are found in peripheral blood and are positive for VEGFR2 and CD34 but have lost CD133, a $120 \mathrm{kDa}$ glycosylated polypeptide $(11,12)$. Only VEGFR2 persists during further endothelial cell differentiation.

In the peripheral circulation, mature endothelial cells are defined as circulating endothelial cells (CECs) and EPCs are defined as circulating endothelial progenitor cells (CEPs) (4). CECs appear in the peripheral circulation due to shedding from activated or damaged tumor vessels. It was reported that the amount of CECs is increased in progressive cancer patients and in several pathologic conditions that involve 
a

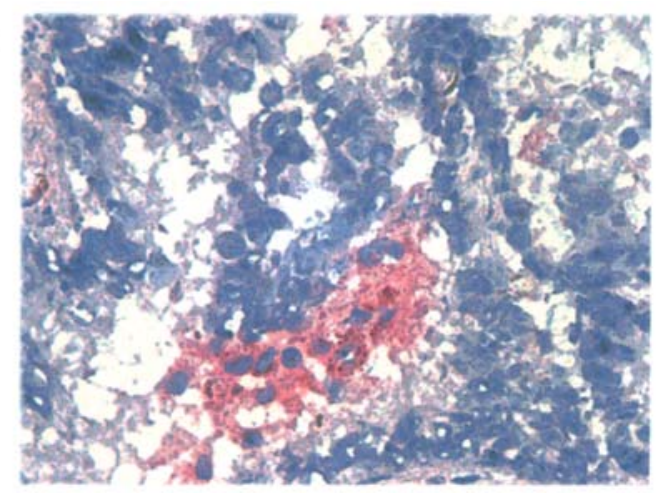

b

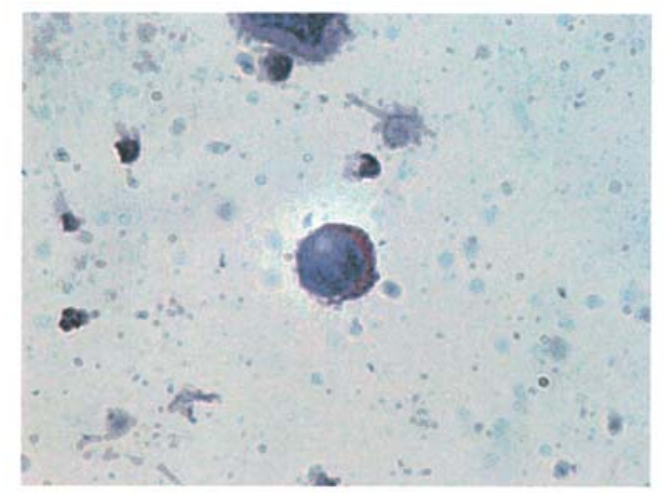

Figure 1. (a) Immunohistochemistry: immunostaining for CD133 in a sequential section of a non-small cell lung cancer specimen. Single positive cells are seen as well as APAAP staining on the cryostat section. (b) MCA staining: immunostaining for CD133 of peripheral MNCs. MCA method, MACS on CD34 selection with a subsequent cytospin cell concentration and at least APAAP staining for CD133.

vascular injury or instability such as myocardial infarction. However, the frequency of CEPs is very low and, therefore, their detection is technically challenging. For example, one study has described the isolation of $645 \mathrm{CD} 34^{+}$cells per milliliter of blood using anti-CD34 antibody-coated magnetic microbeads. Another study reported the number of circulating early $\mathrm{CD} 133^{+} / \mathrm{CD} 34^{+} / \mathrm{VEGFR} 2^{+}$postnatal EPCs in healthy human subjects to be within the range of $0.002 \%$ of total peripheral blood mononuclear cells, corresponding to $\sim 70-210$ cells $/ \mathrm{ml}$ (12). Thus, the number of EPCs in healthy subjects is low and correlates with the low number of circulating vessel wall-derived endothelial cells (CEC) (13). In addition, this issue is complicated by the fact that clear definitions of this cell population do not exist.

However, the clinical relevance of EPC on blood vessel formation in NSCLC patients is still unclear. In this study, we quantified mature and early EPCs in the peripheral blood of non-small cell lung cancer patients undergoing surgical therapy. The measurements were done according to fixed timetables before and after surgery. The amounts of EPCs were correlated with serum levels of angiogenic growth factors (VEGF) as well as the percentage of CD133+ cells in fresh-frozen tumor specimens.

\section{Patients and methods}

Patients. The study was approved by the regional ethics board of Innsbruck, Austria. Inclusion criteria were operable patients with stage IB-IIB disease according to UICC. At the time of study entry the patients had to be free of additional malignant, inflammatory or ischemic diseases, wounds or ulcers that may influence the numbers of EPCs (12). EDTA and serum blood samples had to be taken before and 10 days after surgical therapy. As a control, blood samples of five healthy donors were analyzed. For immunohistological staining, tumor tissue was obtained and was fresh-frozen immediately.

Isolation of mononuclear cells and MACS CD34+ cell isolation. EDTA blood $(45 \mathrm{ml})$ was suspended in PBS containing $0.5 \%$ BSA and 2 mM EDTA, pH 7.2. Mononuclear cells (MNCs) were isolated from the peripheral blood using Ficoll-Hypaque density gradient centrifugation. After centrifugation (400 $\mathrm{g}$ for $20 \mathrm{~min}$, without a break) the mononuclear cell layer was carefully transfered into a new tube, washed three times in PBS containing 0.5\% BSA and 2 mM EDTA, $\mathrm{pH}$ 7.2. Then the cells were counted with a Neubauer counting chamber.

MNCs were incubated for $30 \mathrm{~min}$ on ice with CD34 microbeads. The CD34 microbead system from Miltenyi was used (Miltenyi direct CD34 progenitor cell isolation kit, Miltenyi Biotec, Bergisch Gladbach, Germany). After the magnetic labelling of the cells, the suspension was loaded onto a MACS Column (MS Columns, Miltenyi Biotec) which was placed in the magnetic field of a MACS Separator (Octo MACS Cell Separator, Miltenyi Biotec). The magneticallylabelled $\mathrm{CD} 4^{+}$cells were retained within the column. After removing the column from the magnetic field, the magnetically-retained $\mathrm{CD} 34^{+}$cells were eluted as a positively-selected cell fraction. The $\mathrm{CD}^{3} 4^{+}$cells were counted with the Neubauer counting chamber. After the positive selection, CD34 MNCs were divided in two groups. One group underwent FACS analysis. The other group was assessed by immunocytological staining for CD133 (MCA).

Immunocytological staining of singular CEPs (The MCA method) (Fig. 1b). This method combines a CD34 MACS selection with a subsequent cytospin cell concentration and at least APAAP staining for CD133. A minimum of 40,000 $\mathrm{CD} 34^{+}$cells were centrifuged, slides were dried for one day at room temperature and then fixed with formalin for $5 \mathrm{~min}$.

After fixation the cytospin slides were incubated with the monoclonal antibody against CD133 (Miltenyi CD133/1 AC133 pure, Miltenyi Biotec) at appropiate dilutions and then incubated with an alkaline phosphatase complex [Vector red alkaline phosphatase substrate kit I (Vector, Burlingame, CA, USA)]. The primary and secondary antibodies were diluted with phosphate-buffered saline with $1 \%$ bovine serum albumin.

FACS analysis of $\mathrm{CD}^{3} 4^{+}$cells (Fig. 2). For FACS (fluorecenceactivated cell sorting) analysis, 50,000 CD34+ cells were acquired and scored with a cytomics FC 500 MPL flow cytometry system (Beckman Coulter). The following antibodies were used: $2 \mu 1$ anti-h VEGFR2 PE (KDR; R\&D systems, Minneapolis, MN, USA), $2 \mu 1$ CD133/2 (293C3) 
a

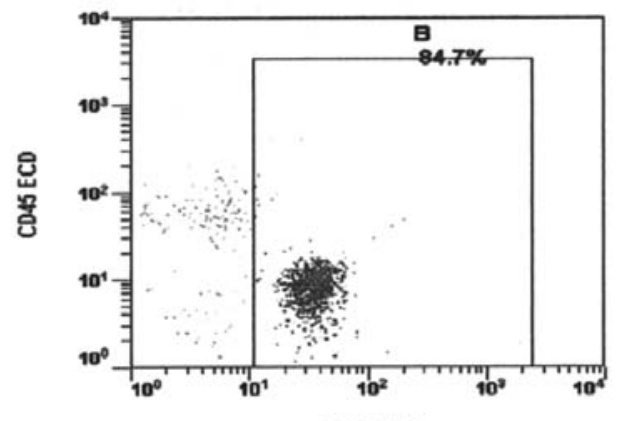

$\cos 4$ PC7

C

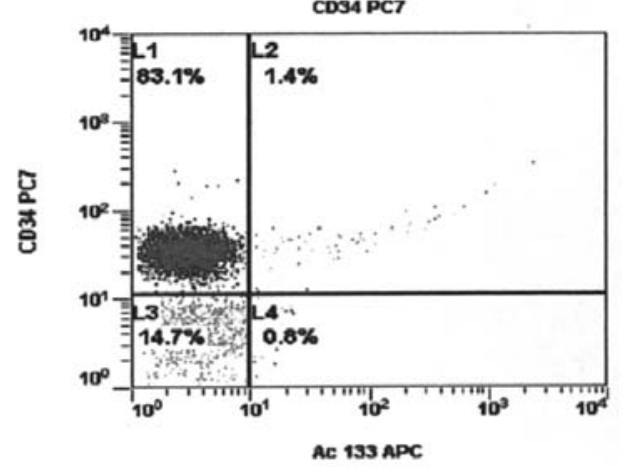

b

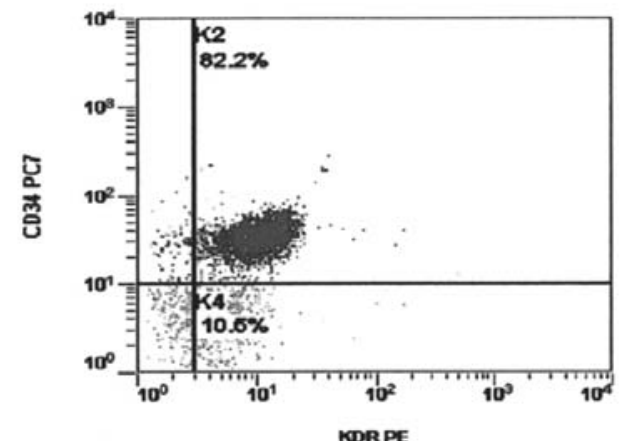

d

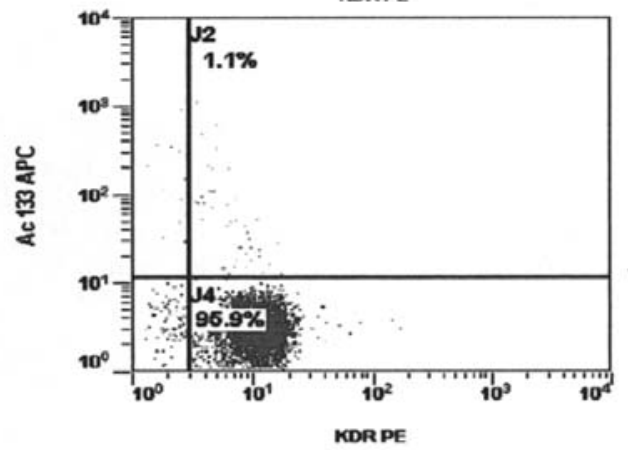

Figure 2. FACS analysis. (a) CD34+ cells. (b) CD34+/VEGFR2 + KDR) double-positive late EPCs. (c) CD34+/CD133+ double-positive EPCs. (d) Triple-positive cells were identified by the dual expression of VEGFR2 and CD133 within the CD34-gated population.

APC (MACS Miltenyi, Miltenyi Biotec), $2 \mu 1$ CD34 PC7 (Beckman Coulter, Fullerton, CA, USA), $2 \mu 1$ CD45 ECD (Beckman Coulter).

FACS analysis started with a 2-dimensional side-/forwardscatter dot-plot analysis to include MNCs exclusively. Then $\mathrm{CD}^{2} 4^{+}$cells (Fig. 2a) were gated within the defined MNC cell fraction. This population was further defined by a dual expression of CD34+/VEGFR2 ${ }^{+}$(KDR) (Fig. 2b) or CD $34^{+} /$ $\mathrm{CD} 33^{+}$(Fig. 2c). Triple-positive cells were identified by the dual expression of VEGFR2 and CD133 within the CD34gated population (Fig. 2d).

Measurement of angiogenic factors. For the serum samples, blood was withdrawn in S-Monovette serum tubes $(7.5 \mathrm{ml})$. The samples were immediately centrifuged at 1,700 $\mathrm{g}$ and supernatants were stored at $-80^{\circ} \mathrm{C}$. For a quantitative measurement of soluble VEGF, a commercially available ELISA (human VEGF immunoassay, quantikine, R\&D systems, Minneapolis, MN, USA) was used according to the manufacturer's guidelines.

Immunohistochemical CD133 staining of frozen tumor specimens (Fig. 1a). Frozen specimens were cut at 5-7 $\mu \mathrm{m}$ in a cryostat, fixed, incubated with monoclonal antibodies at appropriate dilutions and then incubated with an alkaline phosphatase complex (Vector red alkaline phosphatase substrate kit I, Burlingame) as previously described (14). All antibodies were diluted with phosphate-buffered saline with $1 \%$ bovine serum albumin. The following antibodies were used: CD133 (Miltenyi CD133/1 AC133 pure, Miltenyi Biotec) to analyze the endothelial progenitor cells, CD31 (BD Pharmingen, Erembodegem, Belgium) to define the tumor vasculature, IgG1 (eBioscience,(San Diego, CA, USA) and for control cytokeratin A7 was applied to mark tumor cells (Chemicon, Billerica, MA, USA).

Immunocytological and immunohistochemical evaluation. Slides were evaluated independently by two of the authors (A.P. and W.H.) using a semi-quantitative method on a Zeiss AXIOSKOP 2 microscope. Immunopositive cells were counted in reprensentative areas of the sections and quantified as a percentage. The intensity of immunostaining was divided into four categories: negative (-), low (+), moderate $(++)$ and high $(+++)$. Based on the results achieved on a tumor-free tissue of a historical control (14), the cut-off level was defined as $>0.7 \%$ for CD133.

Only cases with moderate $(++)$ or high $(+++)$ staining intensity and a percentage of immunopositive cells above the cut-off point were scored as positive.

Statistical analysis. The Pearson $\chi^{2}$ test was applied to evaluate the differences between the groups. Statistical significance was determined using $95 \%$ confidence intervals. All statistical procedures were performed with SPSS, version 7.5, statistical software (SPSS, Inc., Chicago, IL).

\section{Results}

Patients. According to protocol, 10 patients were included in the study. All patients and controls gave their written informed consent before study entry. The patients were treated surgically with a primarily curative intention. Histological work-up revealed UICC stage IA in three cases, IB in three cases, IIA in one case and IIB in two cases. Only one patient, primarily assumed to be in a local stage, was revealed to be a stage IIIB in the pathological diagnosis and 
Table I. Results of the MCA method.

\begin{tabular}{llllll}
\hline & & $\begin{array}{l}\text { Median in } \% \\
\text { (range) }\end{array}$ & Cut-off & \% positive & p-value $^{\text {a }}$ \\
\hline${\mathrm{CD} 133^{+}}$ & preoperative & $1.25(0.75-1.59)$ & 0.97 & 80 & $\mathrm{p}=0.001$ \\
${\mathrm{CD} 133^{+}}$ & postoperative & $0.81(0.38-1.30)$ & 0.97 & 50 & $\mathrm{p}=0.058$ \\
\hline
\end{tabular}

Results of the MCA method: method applied, monoclonal antibody used, time of blood analysis (pre- or postoperative), median (range) number of positive cells, predefined cut-off level, percentage of patients above that cut-off and statistical difference when compared with the controls. ${ }^{\mathrm{a}}$

Table II. Results of the FACS method.

\begin{tabular}{|c|c|c|c|c|c|}
\hline & & Median in \% (range) & Cut-off & $\%$ positive & $\mathrm{p}$-value ${ }^{\mathrm{a}}$ \\
\hline $\mathrm{CD}^{4+} / \mathrm{CD} 133^{+}$ & preoperative & $0.4(0.2-3.5)$ & 0.55 & 40 & n.s. \\
\hline $\mathrm{CD} 4^{+} / \mathrm{CD} 133^{+} / \mathrm{KDR}^{+}$ & preoperative & $0.3(0.1-2.1)$ & 0.38 & 50 & $\mathrm{p}=0.580$ \\
\hline $\mathrm{CD} 34^{+} / \mathrm{KDR}^{+}$ & preoperative & $89.6(56.8-95.2)$ & 73.00 & 90 & $\mathrm{p}=0.000$ \\
\hline $\mathrm{CD} 133^{+}$ & preoperative & $0.2(0-1.4)$ & 0.39 & 40 & n.s. \\
\hline $\mathrm{CD} 4^{+} / \mathrm{CD} 133^{+}$ & postoperative & $1.15(0.2-2.00)$ & 0.55 & 80 & $\mathrm{p}=0.001$ \\
\hline $\mathrm{CD} 4^{+} / \mathrm{CD} 33^{+} / \mathrm{KDR}^{+}$ & postoperative & $0.55(0.1-0.9)$ & 0.38 & 80 & $\mathrm{p}=0.001$ \\
\hline $\mathrm{CD} 34^{+} / \mathrm{KDR}^{+}$ & postoperative & $94.55(88.00-97.70)$ & 73.00 & 100 & $\mathrm{p}=0.000$ \\
\hline CD133+ & postoperative & $0.50(0-0.70)$ & 0.39 & 70 & $\mathrm{p}=0.075$ \\
\hline
\end{tabular}

Results of the FACS method: method applied, monoclonal antibody used, time of blood analysis (pre- or postoperative), median (range) number of positive cells, predefined cut-off level, percentage of patients above that cut-off and statistical difference, when compared with the controls. ${ }^{\text {a }}$

a stage IV in the postoperative evaluation. The mean age of the patients was 61.4 years (range 45-73 years) with 5 males and 5 females.

The MCA method showed elevated EPC levels in the peripheral circulation. The definition of the cut-off level was 0.97 (mean percentage of CD133+ cells of the control group plus 2x standard deviations).

Compared to the control group, significantly elevated $\mathrm{CD}_{133^{+}}$cells were found in the peripheral circulation of the NSCLC patients (Table I). The CD133+ cells were elevated significantly at both reading points, before and after surgery. After surgery the $\mathrm{CD} 133^{+}$numbers decreased beyond the predefined cut-off level in five patients while the other patients still had elevated CD133+ levels. In NSCLC patients before surgery, the median value of circulating $\mathrm{CD} 133^{+}$cells was $1.25 \%$ (range $0.75-1.59 \%$ ) of the $\mathrm{CD}_{3} 4^{+}$-enriched cells. After surgery the median value of the circulating CD133+ cells was $0.81 \%$ (range $0.39-1.30 \%$ ) of the CD34+-enriched cells.

In the control group the median was $0.51 \% \mathrm{CD} 133^{+}$ (range $0.22-0.83 \%$ ). As regards to the predefined cut-off value, all samples of healthy controls were CD133.

FACS analysis (Table II) showing elevated numbers of $\mathrm{CD}_{34} / \mathrm{VEGFR} 2^{+}(\mathrm{KDR})$ cells pre- and postoperative. In the control group a median of $42 \%$ (range 6.6-51.4\%) $\mathrm{VEGFR}^{+}$ (KDR) cells were found within the $\mathrm{CD}_{3} 4^{+}$-enriched cell population. Applying the predefined cut-off value (cut-off value: $73 \%$, mean percentage of $\mathrm{CD}^{2} 4^{+} / \mathrm{VEGFR}^{+}$cells of the control group plus $2 \mathrm{x}$ standard deviations) all measurements $(100 \%)$ remained below this value. Patients showed elevated numbers of CD34+/VEGFR2+ (KDR) cells, preoperative in $9 / 10$ and postoperative in $10 / 10$ cases. In NSCLC patients before surgery, the median percentage of CD34-enriched cells with a coexpression of VEGFR2 ${ }^{+}$was $90 \%$ (range 5795\%) and postoperative $95 \%$ (range $88-98 \%$ ).

Elevated counts of early EPCs $\left(\mathrm{CD}^{2} 4^{+} / \mathrm{VEGFR}^{+} / \mathrm{CD} 133^{+}\right)$in the peripheral circulation. In the control group the median of $\mathrm{CD}_{133}+\mathrm{VEGFR}^{+}$cells was $0.1 \%$ (range $0.0-0.3 \%$ ) of CD34enriched cells. All measurements $(100 \%)$ in the control group were under the predefined cut-off value (cut-off value: 0.55 ,

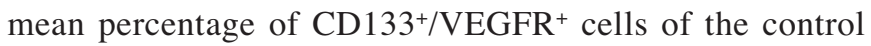
group plus $2 \mathrm{x}$ standard deviations). Within the CD34+enriched population, the CD133+/VEGFR2 ${ }^{+}$(KDR) cells were elevated in the preoperative samples in $50 \%$ and in the postoperative ones in $80 \%$ of the patients. The median percentage of $\mathrm{CD}_{34}+\mathrm{CD} 133^{+} / \mathrm{VEGFR} 2{ }^{+}$was $0.3 \%$ (range $0.1-2.1 \%$ ) in the preoperative samples and $0.55 \%$ (range $0.1-0.9 \%$ ) in the postoperative ones.

Highly elevated serum ELISA VEGF levels pre-and postoperatively. In the control group the median VEGF level was $131 \mathrm{pg} / \mathrm{ml}$ (range 70-294 pg/ml). Based on these results, the cut-off level was defined as $351 \mathrm{pg} / \mathrm{ml}$ (mean percentage of VEGF values of the control group plus $2 x$ standard 
Table III. Correlations of the results achieved by MCA, FACS, immunohistochemical tissue analysis and VEGF levels.

\begin{tabular}{|c|c|c|c|c|c|c|c|c|c|c|c|c|c|c|}
\hline Method & & & $\begin{array}{l}\text { S } \\
\text { \& } \\
\end{array}$ & 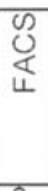 & $\begin{array}{l}\mathscr{W} \\
\mathbb{4} \\
\mathbb{4}\end{array}$ & $\begin{array}{l}\text { S } \\
\mathbb{U} \\
\mathbb{4}\end{array}$ & $\begin{array}{l}\frac{0}{4} \\
\frac{1}{4} \\
\frac{1}{4}\end{array}$ & $\frac{\mathbb{6}}{\frac{\omega}{4}}$ & $\begin{array}{l}\mathscr{W} \\
\mathbb{4} \\
\end{array}$ & 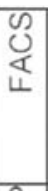 & $\begin{array}{l}\mathscr{S} \\
\stackrel{4}{4}\end{array}$ & $\begin{array}{l}\frac{0}{4} \\
\frac{1}{4} \\
\frac{0}{4}\end{array}$ & $\frac{\frac{6}{\omega}}{\frac{\omega}{w}}$ & 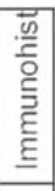 \\
\hline & Date & & $\begin{array}{l}0 \\
0 \\
0 \\
0\end{array}$ & $\begin{array}{l}0 \\
0 \\
\frac{1}{2}\end{array}$ & $\begin{array}{l}0 \\
0 \\
0 \\
\vdots\end{array}$ & $\begin{array}{l}0 \\
0 \\
0 \\
\vdots\end{array}$ & $\begin{array}{l}0 \\
0 \\
0 \\
0\end{array}$ & $\begin{array}{l}0 \\
0 \\
0 \\
0\end{array}$ & 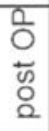 & $\begin{array}{l}0 \\
0 \\
5 \\
0 \\
0\end{array}$ & $\begin{array}{l}0 \\
0 \\
5 \\
0 \\
0\end{array}$ & $\begin{array}{l}0 \\
0 \\
5 \\
0 \\
0\end{array}$ & $\begin{array}{l}0 \\
0 \\
\text { o } \\
0 \\
\Sigma\end{array}$ & \\
\hline & & Parameter & 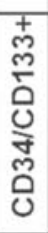 & 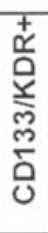 & 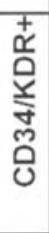 & 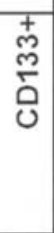 & $\begin{array}{l}\stackrel{+}{\text { m}} \\
\stackrel{\text { m}}{0}\end{array}$ & $\begin{array}{l}\frac{1}{J} \\
\text { 岁 }\end{array}$ & 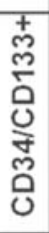 & 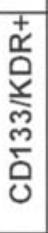 & $\begin{array}{l}+ \\
\stackrel{m}{m} \\
\stackrel{9}{0}\end{array}$ & 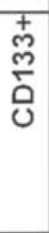 & $\begin{array}{l}\frac{1}{0} \\
\text { Ш }\end{array}$ & \\
\hline FACS & pre OP & CD34/CD133+ & & $\bullet$ & $x$ & $\bullet$ & $x$ & $x$ & 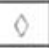 & $\theta$ & $x$ & $x$ & $x$ & $\lambda$ \\
\hline FACS & pre OP & CD133/KDR+ & $\bullet$ & & $x$ & $\bullet$ & $x$ & $x$ & $x$ & $x$ & $\mathrm{x}$ & $x$ & $x$ & $x$ \\
\hline FACS & pre OP & CD34/KDR+ & $x$ & $x$ & & $x$ & $\bullet$ & $\mathrm{X}$ & $\mathrm{x}$ & $\mathrm{X}$ & $\mathrm{x}$ & $\mathrm{x}$ & $x$ & $x$ \\
\hline FACS & pre OP & CD133+ & $\bullet$ & $\bullet$ & $x$ & & $x$ & $x$ & 0 & 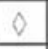 & $\mathrm{x}$ & $x$ & $x$ & $x$ \\
\hline APAAP & pre OP & CD133+ & $x$ & $x$ & $\bullet$ & $x$ & & $x$ & $x$ & $\mathrm{X}$ & $x$ & $x$ & $x$ & $x$ \\
\hline ELISA & pre OP & VEGF & $x$ & $x$ & $x$ & $x$ & $x$ & & $x$ & $\mathrm{X}$ & $\mathrm{x}$ & $\bullet$ & $x$ & $\mathrm{X}$ \\
\hline FACS & post OP & CD34/CD133+ & 0 & $x$ & $x$ & $\theta$ & $x$ & $x$ & & $x$ & $\bullet$ & $x$ & $x$ & $x$ \\
\hline FACS & post OP & CD133/KDR+ & $\theta$ & $x$ & $x$ & 0 & $x$ & $x$ & $x$ & & $x$ & $x$ & $x$ & - \\
\hline FACS & post OP & CD133+ & $x$ & $x$ & $x$ & $x$ & $\mathrm{X}$ & $x$ & $\bullet$ & $\mathrm{X}$ & & $\mathrm{X}$ & $x$ & $X$ \\
\hline APAAP & post OP & CD133+ & $x$ & $x$ & $x$ & $x$ & $x$ & $\bullet$ & $x$ & $x$ & $x$ & & $x$ & $\bullet$ \\
\hline ELISA & post OP & VEGF & $x$ & $x$ & $x$ & $x$ & $x$ & $x$ & $x$ & $x$ & $x$ & $x$ & & $x$ \\
\hline Immunohist & & & $x$ & $x$ & $x$ & $x$ & $X$ & $x$ & $x$ & $\bullet$ & $x$ & $\bullet$ & $X$ & \\
\hline
\end{tabular}

$\bullet$, statistically significant; $\searrow$, negative statistical significance; $X$, no correlation.

deviations). A serum analysis of VEGF values showed preand postoperatively highly elevated levels when compared to the control group, $60 \%$ of the patients preoperatively had elevated VEGF levels (median 418 pg/ml, range 63-811 pg/ml) and $90 \%$ postoperatively. The median postoperative value was $1109 \mathrm{pg} / \mathrm{ml}$ (range $230-2193 \mathrm{pg} / \mathrm{ml}$ ).

Immunohistochemistry: 7/10 tumor samples, had increased numbers of $\mathrm{CD} 133^{+}$EPCs. Increased numbers of CD133+ cells were found in 7 out of 10 patients within the tumor group and some cases revealed capillary-forming structures which were positive for CD133 staining. The cut-off value, $0.7 \% \mathrm{CD} 133^{+}$cells, had already been defined in a previous study (14). In the present study the median of CD133+ cells was $1.2 \%$ (range $0.4-5 \%$ ).

Correlations. The Pearson $\chi^{2}$ test was applied to evaluate differences between the groups. Table III shows the results of the correlation analysis. Important correlations included the preoperative double staining of $\mathrm{CD} 133^{+} / \mathrm{CD} 34^{+}$or $\mathrm{CD} 133^{+/}$ $\mathrm{VEGFR}^{+}$(KDR) correlated significantly with the single staining of CD133 in the FACS analysis. Results of the classical EPC FACS staining method CD34+/VEGFR2+ (KDR) correlated significantly with those generated by the new MCA method. The preoperative VEGF serum value did not correlate with the number of EPCs in the circulation and the CD133+

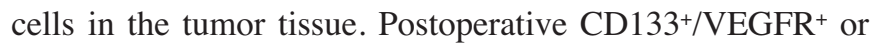
CD133+/CD34 correlated with single CD133 staining (FACS).
Comparison between the FACS, MCA and ELISA methods. For statistical reasons, the preoperative and postoperative results were merged $(n=20)$ to improve the explanatory power of each technical method. The details are listed in Table IV.

In this analysis, increased VEGF levels were more frequently seen in patients with elevated EPC counts $\left(\mathrm{CD} 34^{+}{ }^{+}\right.$EGFR2 $\left.{ }^{+}\right)(\mathrm{p}=0.083)$. The above-mentioned results were confirmed in the mixed sub-analysis.

\section{Discussion}

Based on a mouse model $(15,16)$, endothelial progenitor cells (EPCs) are supposed to play a role in tumor angiogenesis and VEGF was proven to recruit these cells from the bone marrow. However, there is little data supporting this concept in patients and there is still no method of EPC detection in vivo which can be regarded as the 'Gold Standard'. Therefore, the present study investigated EPCs in the circulation and tumor specimens as well as VEGF levels during the therapy of primarily curable NSCLC patients before and after surgical treatment. Secondly, different techniques were applied and compared to each other.

As one result, EPC levels in the circulation and tumor tissue are increased in NSCLC patients compared to healthy controls. These findings are consistent with a previous report showing increased EPC levels in 22 surgically-treated NSCLC patients (17). 
Table IV. MCA vs. FACS vs. VEGF analysis, based on the pooled data set (pre- and postoperative data).

\begin{tabular}{|c|c|c|c|c|c|c|c|}
\hline \multicolumn{2}{|l|}{ Method } & \multirow{2}{*}{$\frac{\text { FACS }}{\mathrm{CD}^{2} 4^{+} / \mathrm{CD} 133^{+}}$} & \multirow{2}{*}{$\begin{array}{l}\text { FACS } \\
{\mathrm{CD} 34^{+} / \mathrm{CD} 133 / \mathrm{KDR}^{+}}^{+}\end{array}$} & \multirow{2}{*}{$\begin{array}{l}\text { FACS } \\
{\mathrm{CD} 34^{+} / \mathrm{KDR}^{+}}^{+}\end{array}$} & \multirow{2}{*}{$\frac{\text { FACS }}{\mathrm{CD} 133^{+}}$} & \multirow{2}{*}{$\frac{\text { APAAP }}{\mathrm{CD}^{2} 33^{+}}$} & \multirow{2}{*}{$\frac{\text { ELISA }}{\text { VEGF }}$} \\
\hline & Parameter & & & & & & \\
\hline FACS & $\mathrm{CD} 34^{+} / \mathrm{CD} 133^{+}$ & & $\mathrm{p}=0.001$ & $\mathrm{X}$ & $\mathrm{p}=0.000$ & $\mathrm{X}$ & $X$ \\
\hline FACS & $\mathrm{CD} 4^{+} / \mathrm{CD} 133^{+} / \mathrm{KDR}^{+}$ & $\mathrm{p}=0.001$ & & $\mathrm{X}$ & $\mathrm{p}=0.005$ & $\mathrm{X}$ & $\mathrm{X}$ \\
\hline FACS & $\mathrm{CD}^{4} 4^{+} / \mathrm{KDR}^{+}$ & $\mathrm{X}$ & $\mathrm{X}$ & & $\mathrm{X}$ & $\mathrm{X}$ & $\mathrm{p}=0.083$ \\
\hline FACS & $\mathrm{CD}_{133^{+}}$ & $\mathrm{p}=0.000$ & $\mathrm{p}=0.005$ & $\mathrm{X}$ & & $\mathrm{X}$ & $\mathrm{X}$ \\
\hline APAAP & CD133+ & $X$ & $\mathrm{X}$ & $\mathrm{X}$ & $X$ & & $X$ \\
\hline ELISA & VEGF & $\mathrm{X}$ & $\mathrm{X}$ & $\mathrm{p}=0.083$ & $\mathrm{X}$ & $\mathrm{X}$ & \\
\hline
\end{tabular}

Compared to the controls, the VEGF serum levels were highly elevated and in a pooled analysis of pre- and postsurgery measurements only a statistical trend between EPC numbers and VEGF levels was detected. Similarly, Fürstenberger et al (18) analyzed circulating endothelial progenitor cells (CEPs) and VEGF levels in 26 patients with breast cancer and failed to prove a significant correlation between these two parameters. Taking into account that the recruitment of EPCs is influenced by a cocktail of cytokines, the low dependency between a single growth factor (VEGF) and EPC count is not surprising (12).

From a technical point of view there are still many open questions to discuss such as how to enrich EPCs, how to measure them and how to define them immunologically. Due to the very low numbers of EPCs in the peripheral blood the measurement is technically challenging. Peichev et al (8) calculated that the cell counts of EPCs in the peripheral blood showing a CD $34^{+} / \mathrm{AC} 133^{+} / \mathrm{VEGFR} 2^{+}$profile is $0.002 \%$ of the MNCs. This is equivalent to $0.4 \% \pm 0.2 \%$ of the $\mathrm{CD}^{+} 4^{+}$ cell fraction. Moreover, Peichev showed that EPCs were 10fold mobilized by stimulation with G-CSF $(0.02 \%$ of MNCs or $2 \%$ of $\mathrm{CD} 4^{+}$cells). Until now the most applied method of EPC detection is FACS analysis, although the very rare number of EPCs within the mononuclear cell (MNC) fraction limits its utility (18). One way to bypass this problem is EPC enrichment methods such as magnetic associated cell sorting (MACS) using an EPC marker $(8,10,19,20)$.

On the one hand, we have the problem of the low numbers of EPCs in the circulation and on the other hand, the problem of the inconsistent immunological characterisation of EPCs. As yet, there is no clear definition of the antigenic profile of EPCs $(17,21)$. The most common approach is to separate the EPC profile into 'early unmature EPCs' and 'late mature EPCs'. Late EPCs are characterised by a double expression of CD34+and VEGFR2+ (KDR) (22-25). Early EPCs are characterised by a triple positivity of CD34/VEGFR2/CD133. In the peripheral circulation, more mature EPCs are found which have lost the expression of $\mathrm{CD} 133^{+}$. The loss of CD133 may be the timepoint when EPCs in vivo turn into mature fully-differentiated endothelial cells (12). The starting point of this differentiation process may be the migration of EPCs from the bone marrow to the systemic circulation. After homing, adhesion and insertion into the monolayer of the surrounding mature vascular ECs, this process may be completed (18). However, this definition is mainly of theoretical implication since most authors testing human probes in vivo do not differentiate between 'early immature triple positive' and 'late mature - double positive' EPCs (26-30) while others, who mainly applied immunohistochemistry, define EPCs just by a single CD133 expression $(14,17)$.

The FACS analysis of different subpopulations revealed in our cohort that $90 \%$ of $\mathrm{CD}_{3} 4^{+}$cells were also stained for VEGFR2. Therefore, the VEGFR2 expression seemed to add little to further discriminate this cell population. This experience is supported by Lambiase et al (31) showing that all KDR positive cells expressed CD133. A different approach was chosen by Urbich et al (32) who stated that CD34 is not exclusively expressed on hematopoietic stem cells and that CD133+VEGFR2+ cells more likely reflect immature progenitor cells than $\mathrm{CD} 34^{+} \mathrm{VEGFR}^{+}$cells. Based on these data, in our opinion, a practical approach in identifying early EPC is at least a double staining of CD34 or VEGFR2 plus CD133. The above-mentioned technical limitations prompted our study group to test an alternative method called MCA. MCA combines CD34 MACS pre-selection with subsequent cytospin cell concentration and APAAP immunocytological staining for CD133. An advantage of the MCA method is its high sensitivity for the detection of small cell populations and even single positive cells with the CD133 expression. It is also possible to assess the morphology of single cells (size, integrity, core-plasma relation and granularity) under the microscope. After testing this method on healthy controls, patients were analyzed and results were compared to those achieved by standard FACS analyses (33). Preoperatively $80 \%$ of the patients showed elevated MCA values. The measurements correlated statistically significantly $(\mathrm{p}=0.035)$ with preoperative FACS results of the $\mathrm{CD}^{2} 4^{+}$and VEGFR2 ${ }^{+}$(KDR) cells. This point underlines the quality of the MCA method.

Using FACS analysis, the limits of sensitivity are frequently exceeded. The measuring of very small cell populations with subsequent gating of subpopulations may be responsible for some unreliable results (33). Applying the MCA method, two different trends were observed regarding the pre- and postoperative EPC levels. In five patients, EPC numbers decreased to below the predefined cut-off value whereas another five patients remained at the preoperatively elevated EPC levels. Notably, we were not able to demonstrate the same dynamic when applying FACS analysis. Similarly, 
Dome et al (17) proved that EPC levels were significantly increased in NSCLC patients before surgical treatment. Additionally, NSCLC patients with high pre-treatment FACS CD $34^{+}$VEGFR2 ${ }^{+}$levels had a worse outcome than patients with lower levels. One explanation for this phenomenon is that higher levels of EPCs may be a surrogate for an increased alteration or activity of the tumor vasculature.

Another aim of this study was to assess the influence of VEGF on the recruitment of EPCs from the bone marrow. All patients showed statistically-elevated VEGF levels compared to the healthy controls. Notably, the VEGF levels did not decrease after removal of the tumor. On the other hand, it has to be considered that VEGF levels were certainly influenced by the wound healing process. According to protocol, the postoperative assessment had to be performed prior to potential adjuvant therapies. Yet within that period wound healing had not been completed.

In conclusion, EPCs and VEGF levels are increased in operable lung cancer patients. However, the optimal method in determining CECs or EPCs in vivo is still a matter of debate. The present study pointed out the technical limitations of the frequently used FACS method and presented an alternative MCA method. This MCA procedure proved to be a valuable alternative for the detection of EPCs in the peripheral blood, because of its ability to measure even singular positive cells.

\section{Acknowledgements}

The study was supported by the Association for Cancer Research - Innsbruck (Verein für Tumorforschung Innsbruck), by Medizinischer Forschungsfonds Tirol (MFF) and the Austrian Science Funds NFN-92 and Tiroler Krebsforschung.

\section{References}

1. Parkin DM, Pisani P and Ferlay J: Global cancer statistics. CA Cancer J Clin 49: 33-64, 1999.

2. Shepherd FA, Rodrigues PJ, Ciuleanu T, Tan EH, Hirsh V, Thongprasert S, Campos D, Maoleekoonpiroj S, Smylie M, Martins R, van Kooten M, Dediu M, Findlay B, Tu D, Johnston D, Bezjak A, Clark G, Santabarbara P and Seymour L: Erlotinib in previously treated non-small-cell lung cancer. N Engl J Med 353: 123-132, 2005.

3. Sandler A, Gray R, Perry MC, Brahmer J, Schiller JH, Dowlati A, Lilenbaum R and Johnson DH: Paclitaxel-carboplatin alone or with bevacizumab for non-small-cell lung cancer. N Engl J Med 355: 2542-2550, 2006.

4. Ribatti D: The involvement of endothelial progenitor cells in tumor angiogenesis. J Cell Mol Med 8: 294-300, 2004.

5. Carmeliet P and Jain RK: Angiogenesis in cancer and other diseases. Nature 407: 249-257, 2000.

6. Tolnay E, Wiethege T, Kuhnen C, Wulf M, Voss B and Muller KM: Expression of type IV collagenase correlates with the expression of vascular endothelial growth factor in primary non-small cell lung cancer. J Cancer Res Clin Oncol 123: 652-658, 1997.

7. Tsao MS, Liu N, Nicklee T, Shepherd F and Viallet J: Angiogenesis correlates with vascular endothelial growth factor expression but not with $\mathrm{Ki}$-ras oncogene activation in non-small cell lung carcinoma. Clin Cancer Res 3: 1807-1814, 1997.

8. Peichev M, Naiyer AJ, Pereira D, Zhu Z, Lane WJ, Williams M, Oz MC, Hicklin DJ, Witte L, Moore MA and Rafii S: Expression of VEGFR-2 and AC133 by circulating human CD34(+) cells identifies a population of functional endothelial precursors. Blood 95: 952, 2000.

9. Quirici N, Soligo D, Caneva L, Servida F, Bossolasco P and Deliliers GL: Differentiation and expansion of endothelial cells from human bone marrow CD133(+) cells. Br J Haematol 115: 186-194, 2001.
10. Salven P, Mustjoki S, Alitalo R, Alitalo K and Rafii S: VEGFR-3 and CD133 identify a population of CD $34^{+}$lymphatic/vascular endothelial precursor cells. Blood 101: 168-172, 2003.

11. Rafii S: Circulating endothelial precursors: mystery, reality, and promise. J Clin Invest 105: 17-19, 2000.

12. Hristov M, Erl W and Weber PC: Endothelial progenitor cells: mobilization, differentiation, and homing. Arterioscler Thromb Vasc Biol 23: 1185, 2003.

13. Dignat-George F and Sampol J: Circulating endothelial cells in vascular disorders: new insights into an old concept. Eur J Haematol 65: 215-220, 2000.

14. Hilbe W, Dirnhofer S, Oberwasserlechner F, Schmid T, Gunsilius E, Hilbe G, Woll E and Kahler CM: CD133 positive endothelial progenitor cells contribute to the tumour vasculature in non-small cell lung cancer. J Clin Pathol 57: 965, 2004.

15. Lyden D, Hattori K, Dias S, Costa C, Blaikie P, Butros L, Chadburn A, Heissig B, Marks W, Witte L, Wu Y, Hicklin D, Zhu Z, Hackett NR, Crystal RG, Moore MA, Hajjar KA, Manova K, Benezra R and Rafii S: Impaired recruitment of bone-marrow-derived endothelial and hematopoietic precursor cells blocks tumor angiogenesis and growth. Nat Med 7: 1194, 2001.

16. Davidoff AM, Ng CY, Brown P, Leary MA, Spurbeck WW, Zhou J, Horwitz E, Vanin EF and Nienhuis AW: Bone marrowderived cells contribute to tumor neovasculature and, when modified to express an angiogenesis inhibitor, can restrict tumor growth in mice. Clin Cancer Res 7: 2870-2879, 2001.

17. Dome B, Timar J, Dobos J, Meszaros L, Raso E, Paku S, Kenessey I, Ostoros G, Magyar M, Ladanyi A, Bogos K and Tovari J: Identification and clinical significance of circulating endothelial progenitor cells in human non-small cell lung cancer. Cancer Res 66: 7341-7347, 2006.

18. Furstenberger G, von Moos R, Lucas R, Thurlimann B, Senn HJ, Hamacher J and Boneberg EM: Circulating endothelial cells and angiogenic serum factors during neoadjuvant chemotherapy of primary breast cancer. Br J Cancer 94: 524-531, 2006.

19. de Wynter EA, Coutinho LH, Pei X, Marsh JC, Hows J, Luft T and Testa NG: Comparison of purity and enrichment of CD $34^{+}$ cells from bone marrow, umbilical cord and peripheral blood (primed for apheresis) using five separation systems. Stem Cells 13: 524-532, 1995.

20. Yin AH, Miraglia S, Zanjani ED, Almeida-Porada G, Ogawa M, Leary AG, Olweus J, Kearney J and Buck DW: AC133, a novel marker for human hematopoietic stem and progenitor cells. Blood 90: 5002-5012, 1997.

21. Ingram DA, Mead LE, Tanaka H, Meade V, Fenoglio A, Mortell K, Pollok K, Ferkowicz MJ, Gilley D and Yoder MC: Identification of a novel hierarchy of endothelial progenitor cells using human peripheral and umbilical cord blood. Blood 104: 2752-2760, 2004.

22. Werner N, Kosiol S, Schiegl T, Ahlers P, Walenta K, Link A, Bohm M and Nickenig G: Circulating endothelial progenitor cells and cardiovascular outcomes. N Engl J Med 353: 999-1007, 2005.

23. Fadini GP, Miorin M, Facco M, Bonamico S, Baesso I, Grego F, Menegolo M, de Kreutzenberg SV, Tiengo A, Agostini C and Avogaro A: Circulating endothelial progenitor cells are reduced in peripheral vascular complications of type 2 diabetes mellitus. J Am Coll Cardiol 45: 1449-1457, 2005.

24. Adams V, Lenk K, Linke A, Lenz D, Erbs S, Sandri M, Tarnok A, Gielen S, Emmrich F, Schuler G and Hambrecht R: Increase of circulating endothelial progenitor cells in patients with coronary artery disease after exercise-induced ischemia. Arterioscler Thromb Vasc Biol 24: 684-690, 2004

25. Laufs U, Werner N, Link A, Endres M, Wassmann S, Jurgens K, Miche E, Bohm M and Nickenig G: Physical training increases endothelial progenitor cells, inhibits neointima formation, and enhances angiogenesis. Circulation 109: 220-226, 2004.

26. Urbich $\mathrm{C}$ and Dimmeler S: Endothelial progenitor cells functional characterization. Trends Cardiovasc Med 14: 318-322, 2004.

27. Dernbach E, Urbich C, Brandes RP, Hofmann WK, Zeiher AM and Dimmeler S: Antioxidative stress-associated genes in circulating progenitor cells: evidence for enhanced resistance against oxidative stress. Blood 104: 3591-3597, 2004.

28. Kalka C, Masuda H, Takahashi T, Kalka-Moll WM, Silver M, Kearney M, Li T, Isner JM and Asahara T: Transplantation of ex vivo expanded endothelial progenitor cells for therapeutic neovascularization. Proc Natl Acad Sci USA 97: 3422-3427, 2000 . 
29. Miraglia S, Godfrey W, Yin AH, Atkins K, Warnke R, Holden JT, Bray RA, Waller EK and Buck DW: A novel five-transmembrane hematopoietic stem cell antigen: isolation, characterization, and molecular cloning. Blood 90: 5013-5021, 1997.

30. Gehling UM, Ergun S, Schumacher U, Wagener C, Pantel K, Otte M, Schuch G, Schafhausen P, Mende T, Kilic N, Kluge K, Schafer B, Hossfeld DK and Fiedler W: In vitro differentiation of endothelial cells from AC133-positive progenitor cells. Blood 95: 3106, 2000.
31. Lambiase PD, Edwards RJ, Anthopoulos P, Rahman S, Meng YG, Bucknall CA, Redwood SR, Pearson JD and Marber MS: Circulating humoral factors and endothelial progenitor cells in patients with differing coronary collateral support. Circulation 109: 2986-2992, 2004.

32. Urbich C and Dimmeler S: Endothelial progenitor cells: characterization and role in vascular biology. Circ Res 95: 343-353, 2004.

33. Khan SS, Solomon MA and McCoy JP Jr: Detection of circulating endothelial cells and endothelial progenitor cells by flow cytometry. Cytometry B Clin Cytom 64: 1-8, 2005. 